\title{
BANGUNAN MEGALITIK SALAH SATU CERMINAN SOLIDARITAS MASA PERUNDAGLAN
}

Oleh: Sumiati Atmosudiro

Masyarakat perundagian telah mencapai tata kehidupan yang teratur. Kemajuan-kemajuan muncul di segala bidang, baik yang berkaitan dengan usaha untuk meningkatkan kesejahteraan hidup, kesenian maupun kepercayaan. Masyarakat masa ini telah membentuk desa-desa yang luas.

Salah satu contoh desa masa tersebut telah ditemukan dalam ekskavasi di pantai Gilimanuk, Bali (R.P. Soejono, 1977a: 260). Dari jenis-jenis temuan yang berasal dari situs tersebut di atas, diperoleh gambaran tentang salah satu tata kehiciupan masyarakat perundagian, khususnya yang bertempat tinggal di tepi pantai. Dari temuan yang bẻrupa sisa-sisa makanan serta bekas-bekas benda keperluan sehari-hari, dapat diperoleh petunjuk bahwa kehidupan masyarakat di daerah itu, adalah sebagai nelayan (R.P. Soejono, 1977b: 271).

Suatu desa atau perkampungan diperkirakan terdiri dari sekelompok rumah meskipun bentuk rumahnya belum dapat diketahui dengan pasti karena dalam ekskavasi belum ditemukan sisa-sisa bangunan.

Hal ini mungkin disebabkan karena bahan yang digunakan untuk membuat rumah terdiri dari bahan yang mudah rusak, sehingga bekas-bekasnya tidak dapat ditemukan kembali. Sedikit gambaran tentang bentuk rumah masa itu, dapat dilihat berdasarkan lukisan bentuk rumah yang terdapat pada salah satu nekara dari pulau Sangean. Pada nekara Sangean atau nekara maka lamau terdapat lukisan bentuk rumah bertonggak. Rumah ini mempunyai atap berbentuk pelana, dengan dinding-dinding condong keluar, dan dilengkapi dengan tangga masuk. Bentuk rumah semacam ini masih dapat dilihat pada bentuk rumah suku bangsa Sa'dan, Toraja, Sulawesi (H.R. Van Heekeren, 1958: 24).

Di kolong rumah tersebut ada gambar ayam, babi dan anjing. Adanya lukisan hewan itu, dapat memberi suatu pengertian bahwa salah satu fungsi kolong rumah, adalah sebagai kandang hewan ternak, sedang hewan ternaknya adalah ayam, babi dan anjing. Kolong rumah yang digunakan sebagai kandang hewan ternak, masih ditemukan pada beberapa súku bangsa di Indonesia, terutama suku bangsa yang memiliki rumah panggung, seperti misalnya suku bangsa Batak, suku bangsa Sa'dan suku bangsa Sumba dan suku bangsa Dayak. Gambaran tentang hewan ternak yang dilukiskan di kolong rumah tersebut diperkuat dengan data arkeologis yang ditemukan di situs Gilimanuk. Temuan itu berupa tulangtulang binatang yang menunjukkan identitas tulang-tulang babi, anjing dan ayam (R.P. Soejono, 1977a: 273).

Kehidupan menetap dengan susunan masyarakat yang teratur, mempengaruhi proses munculnya ide untuk mencapai kemajuan, antara lain dalam bidang teknologi. Suatu hasil yang penting di bidang ini adalah kemahiran dalam teknik penuangan dan peleburan logam, misalnya perung- 
gu. Kemahiran teknik tuang dan peleburan logam menimbulkan akibat diciptakannya benda-benda perunggu, misalnya kapak, nekara, moko, gelang dan patung perunggu. Hasil teknologi tersebut, selain berfungsi sebagai alat sehari-hari ada pula yang digunakan sebagai benda upacara. Pada umumnya benda upacara itu ditandai oleh cara pengerjaan yang diperindah, yaitu dengan berbagai pola hias.

Adapun benda-benda perunggu yang digunakan sebagai benda upacara adalah kapak tipe IA (kapak tipe Makasar), kapak tipe VII dan tipe VIII atau kapak tipe Roti (R.P. Soejono, 1972: 6). Selain itu juga moko dan nekara.

Di samping kemajuan tersebut di atas, produksi pembuatan gerabah masih memegang peranan penting. Hal ini disebabkan karena peranan gerabah tidak begitu mudah digantikan oleh benda-benda logam.

Bahkan fungsi gerabah mengalami perkembangan, karena tidak hanya di gunakan untuk kebutuhan sehari-hari, melainkan digunakan pula sebagai benda upacara, misalnya sebagai wadah bekal kubur atau wadah penguburan. Data arkeologi yang membuktikan dugaan itu adalah temuan kubur tempayan di Anyer Lor, Banten; Plawangan, Jawa Tengah; dan Melolo, Sumba Timur.

Anggota masyarakat yang mempunyai kepandaian dalam bidang tertentu, misalnya membuat gerabah atau menuang logam, terpadu dalam golongan-golongan yang sesuai dengan kemahiran masing-masing, dan terkenal dengan nama golongan undagi. Walaupun telah muncul golongan yang trampil dalam bidang pertukangan, akan tetapi usaha dalam bidang pertanian tetap merupakan mata pencaharian pokok.

Sejalan dengan kemajuan-kemajuan di atas, pada masa perundagian terjadi pula perkembangan dalam bidang seni hias. Hal ini dibuktikan dengan adanya benda-benda perunggu yang mempunyai hiasan yang sangat indah, seperti misalnya yang terdapat pada nekara, moko atau kapak perunggu.

Berdasar temuan nekara di berbagai tempat di Indonesia yang dikumpulkan di Museum Nasional Jakarta, dapat diketahui bahwa nekara yang ditemukan di Indonesia pada umumnya mempunyai hiasan yang raya. Motif hiasan antara lain berupa: motif pilin (spiral), pilin berganda, lingkaran memusat, garis-garis menyiku (meander), tumpal, garis-garis bergelombang, motif tangga dan tangen (H.R. Van Heekeren, 1958: 97-98). Selain motif-motif hiasan tersebut, dilukiskan pula motif binatang misalnya burung, harimau, kijang. Motif hiasan lain adalah bentuk perahu dan manusia baik secara utuh maupun hanya bagian mukanya.

\section{II}

Nilai-nilai hidup dalam masyarakat perundagian semakin berkembang bila dibandingkan dengan masa sebelumnya, misalnya segi kepercayaan. Unsur yang menonjol dalam kepercayaan masyarakat masa ini adalah pemujaan terhadap nenek moyang. Pengaruh kegiatan ini menimbulkan tata kehidupan yang menjaga agar tingkah laku setiap anggota masyarakat 
di dunia fana sesuai dengan tuntutan hidup di alam arwah. Keberhasilan segala usaha ditentukan oleh adanya kekuatan supernatural, oleh karena itu maka setiap usaha yang penting harus disertai dengan upacara, khusus nya ditujukan untuk memperoleh restu dari arwah nenek moyang (R.P. Soe jono, 1977a: 217).

Konsep kepercayaan tentang adanya kekuatan supernatural dan pemujaan nenek moyang, mengakibatkan munculnya golongan yang mempunyai tugas menjadi penghubung antara masyarakat dan dunia supernatural. Di dalam masyarakat golongan ini menduduki peranan yang penting, karena dengan perantaraan dirinyalah diharapkan nenek moyang melimpahkan kesejahteraan bagi masyarakat. Dalam konsep kepercayaan ini berlaku pula suatu anggapan bahwa kematian seseorang tidak membawa perubahan esensial dalam kedudukan dan sifat seseorang. Sehingga seseorang yang meninggal akan mempunyai kedudukan yang sama seperti ketika masih hidup. Atas dasar anggapan ini, maka roh seseorang yang me ninggal tidak lenyap dan akan hidup abadi di alam arwah. Untuk menjaga agar perjalanan serta kehidupan di alam arwah dapat terjamin sebaikbaiknya, maka berlaku pula kebiasaan pemberian bekal kepada seseorang yang meninggal.

Untuk menjalin hubungan antara roh nenek moyang dengan anggota keluarga khususnya serta anggota masyarakat umumnya, didirikanlah bangunan-bangunan besar, atau lebih terkenal dengan nama bangunan megalithik. Dengan didirikannya bangunan ini, masyarakat mengharapkan agar roh nenek moyang di alam arwah memperoleh ketentraman, sehingga roh nenek moyang tersebut akan memberi kesejahteraan, kesuburan bagi pendiri bangunan megalithik serta masyarakat pada umumnya. Nenek moyang sebagai sumber pemujaan dianggap bersemayam dipuncak gunung. Oleh karena itu maka gunung dalam masyarakat perundagian, mempunyai peranan penting, karena gunung dianggap sebrga' statt tempat suci, sumber potensi dan sebagai sumber kesuburan.

Dari gunung itulah air keluar dan kemudian memberi kehidupan baik bagi sawah-ladang, binatang piaraan, maupun semua makluk di dunia (H.G. Quaritch Wales, 1953: 183). Atas dasar anggapan ini, maka bangunan megalithik pada umumnya didirikan di atas gunung atau diarahkan kegunung.

Bangunan megalithik selain berfungsi seperti tersebut di atas, bertujuan pula sebagai salah satu sarana untuk memperoleh tempat yang layak di alam arwah. Tujuan itu akan tercapai bila diikuti dengan mengadakan pesta-pesta tertentu, dan sebagai titik puncaknya dengan pendirian bangunan megalithik. Dengan demikian bangunan megalithik dapat digunakan sebagai medium penghormatan, tahta kedatangan, sekaligus lam bang dari yang meninggal (R.P. Soejono, 1977a: 191).

Konsep kepercayaan yang mendasari didirikannya bangunan megalithik ternyata hidup subur dalam masyarakat yang universal. Bukti tentang hal ini dapat dilihat dari temuan bangunan megalithik yang tersebar luas di berbagai daerah di Indonesia, bahkan sisa-sisa kelangsungannya masih terdapat di beberapa suku bangsa, misalnya suku bangsa Nias, Toraja, 
Flores dan Sumba. Pada suku bangsa-suku bangsa itu, meskipun sebagian masyarakat telah memeluk suatu agama, akan tetapi upacara-upacara yang berkaitan dengan pemujaan nenek moyang masih tetap mereka lakukan. Hal ini menyebabkan adanya dua jenis bangunan megalithik di Indonesia, yaitu bangunan megalithik yang berasal dari masa prasejarah, khususnya masa bercocok tanam dan masa perundagian, serta bangunan megalithik yang berupa kelangsungan atau tradisi.

Bangunan megalithik sebagai salah satu hasil karya manusia, dapat di kelompokkan menurut bentuk, fungsi dan artinya. Berdasarkan bentuknya dapat dibedakan menjadi beberapa jenis misalnya: menhir, dolmen, bangunan berundak, sarkophagus, kubur peti batu dan sebagainya, sedang menurut fungsi dapat dikelompokkan menjadi: (1) kelompok sarana atau tempat pemujaan: bentuk yang digunakan untuk memenuhi tujuan ini adalah bentuk menhir, menhir berkelompok dan bangunan berundak; (2) kelompok perwujudan nenek moyang atau sebagai penolak bala. Untuk tujuan ini digunakan jenis patung-patung sederhana, termasuk di dalamnya arca menhir; (3) kelompok wadah penguburan; dalam kelompok ini terdapat banyak variasi, misalnya sarkophagus, kubur peti batu, kalamba, waruga, dolmen semu dan watu kandang.

Selain kelompok tersebut, masih ada jenis-jenis bangunan megalithik yang fungsinya masih dipermasalahkan. Jenis-jenis itu adalah batu berlubang, batu lumpang dan batu dakon.

Berdasarkan situs-situs megalithilk yang ditemukan di Indonesia, maka dapat diketahui bahwa jenis-jenis bangunan megalithik yang dimilikinya tidak selalu sama. Dengan demikian ada suatu situs yang memil1ki jenis-jenis lengkap dan ada pula situs yang hanya memiliki jenis-jenis tertentu, tetapi di antara jenis tersebut ada yang khusus. Salah satu contoh situs yang lengkap adalah situs Pasemah, Sumatra Selatan. Situs ini memiliki berbagai jenis bangunan megalithik, misalnya menhir, dolmen, batu lumpang, bangunan berundak, kubur peti batu dan patung-patung. Adapun contoh situs yang memiliki jenis khusus atau dominan, adalah situssitus (1) di daerah Sulawesi Tengah, misalnya situs Bada, Besoa dan Napu, jenis yang dimiliki adalah jenis wadah penguburan yang dinamakan Kalamba dan arca-arca menhir; (2) di daerah Bali yang dominan adalah jenis sarkophagus; (3) di daerah Karanganyar, yaitu di situs Matesih memi liki jenis khusus serta dominan, yaitu jenis watu kandang.

Atas dasar pengamatan terhadap jenis-jenis temuan megalithik di beberapa situs di Indonesia, dapat diketahui bahwa bangunan megalithik pada umumnya dibuat dari batu-batu besar, bahkan ada pula yang mempu nyai ukuran luar biasa besarnya. Sebagai contoh misalnya menhir yang ada di Tinggihari mempunyai tinggi 3,75 meter. Contoh lain adalah sebuah dolmen yang ditemukan di Batu Cawang. Dolmen ini terdiri dari batu datar yang di topang oleh empat buah batu tegak. Batu datar itu mempunyai ukuran panjang 3 meter, sedang tebalnya 0,70 m (Van der Hoop, 1932: $15,19)$. Menhir yang cukup besar dan tinggi ditemukan juga di situs Matesih. Ukuran menhir tersebut adalah kira-kira panjang 3 meter, lebar 2 meter. Jenis megalithik yang cukup besar ditemukan juga di Ba- 
da, antara lain berupa arca menhir. Salah satu arca menhir ini berukuran 4,40 meter, lebar 1,32 meter.

\section{III}

Bertolak dari latar belakang didirikannya bangunan megalithik, maka dapat diambil suatu pengertian bahwa bangunan ini sangat berarti dalam kehidupan masyarakat perundagian, terutama dalam segi religi dan sosial. Kepercayaan terhadap nenek moyang dan supernatural, yang mendasari kehidupan masyarakat waktu itu, merupakan benang pengikat yang kuat untuk membentuk rasa kesetia-kawanan. Rasa solidaritas ini akan tampak jelas bila dilihat pada waktu mendirikan bangunan megalithik, karena dalam mendirikan bangunan megalithik, diperlukan tenaga yang cukup banyak. Suatu jenis bangunan megalithik yang besar tidak mungkin dapat didirikan oleh sekelompok tenaga yang sedikit, apalagi bila bangunan tersebut didirikan di atas gunung.

Setiap anggota masyarakat tanpa ada paksaan, akan bekerja bersamasama, dalam rangka mendirikan bangunan megalithik. Dalam alam pikiran mereka tertanam rasa untuk selalu ikut serta dalam rangka mendirikan bangunan tersebut, karena mereka beranggapan bahwa dengan cara ini akan diperoleh ketentraman dan kesuburan yang dilimpahkan oleh nenek moyangnya. Suatu analogi ethnografi dimungkinkan dapat memberi sedikit gambaran, tentang cara-cara mendirikan suatu jenis bangunan megalithik. Salah satu contoh analogi yang dapat dikemukakan adalah: satu segi kehidupan masyarakat suku bangsa Sumba Timur, sebab suku bangsa tersebut sampai sekarang masih melangsungkan tradisi megalithik.

Sebagian suku bangsa Sumba Timur sampai saat ini masih menganut konsep kepercayaan asli atau kepercayaan marapu. Dalam kepercayaan ini, roh seseorang yang meninggal akan hidup abadi di alam arwah.

Adanya kepercayaan asli itu, menyebabkan kematian seseorang akan di sertai dengan upacara-upacara. Sifat upacara kematian akan lebih menonjol bila dibandingkan dengan upacara siklus kehidupan lainnya.

Apabila telah dilakukan serangkaian upacara kematian, kemudian sebagai upacara yang terakhir dipasanglan sejenis jirat. Penduduk setempat menyebut reti. Salah satu bentuk reti pada prinsipnya adalah bentuk dolmen, karena reti dibentuk dari sebongkah batu yang ditopang oleh batu lain.

Pada umumnya bahan yang digunakan untuk membuat reti, diambil dari suatu tempat tertentu, misalnya di gunung-gunung yang letaknya jauh dari lokasi penguburan. Untuk mengangkat bahan tersebut ke tempat penguburan tentu diperlukan beratus-ratus tenaga, sesuai dengan berat bahan ret tersebut. Kebutuhan tenaga yang cukup banyak itu, dapat dipenuhi dengan jalan mengundang seluruh anggota kabihu (suku), termasuk di dalam undangan ini adalah kabihu yang terikat akibat kawin mawin. Sebagai anggota suku mereka pasti akan datang dan membantu, karena mereka merasa ada suatu ikatan, sebagai akibat adanya konsep kepercayaan yang mereka anut bersama, disamping juga adanya rasa kesetia-kawanan. 
Adapun cara mengangkut bahan batu tersebut adalah sebagai beriikut: anggota kabihu yang sudah berkumpul dibagi menjadi empat kelompok, dua kelompok bertugas menahan dan dua kelompok lainnya bertugas menarik. Untuk memudahkan pelaksanaan, maka batu yang akan diangkut dibagian bawahnya diberi dua tali yang kuat dan panjang. Dua tali tersebut pada bagian belakang dipegang oleh kelompok yang bertugas menahan, sedang dua tali bagian depan dipegang oleh kelompok yang bertugas. menarik. Dalam menjalankan tugas ini, selalu dijaga kekompakan di antara sesama anggota, agar tidak terjadi korban manusia, dan batu itu dapat diangkut sampai ke tujuan.

Berdasarkan uraian di atas, maka tidak terlalu berlebihan apabila bangunan megalithil dianggap sebagai suatu cerminan solidaritas masa perundagian, sebagai akibat adanya konsep kepercayaan yang mendasari kehidupan masyarakat.

Kepustakaan

Heekeren, H.R. Van, 1958

'The Bronze Iron Age of Indonesia", VKI XXIII, s'Gravenhage, 'Martinus Nijhoff.

Hoop, A.N.J. Th. a' Th. van der, Megalithic Remains in South Sumatra. 1932 Translated by W. Shirlan. Inthpen, W.J. Thieme \& Cie.

Soejono, R.P.

"'The Distribution of Types of Bronze Age In Indonesia" Bulletin of the Archaeological Institute of the Republic of Indonesia, no. 9, Jakarta.

$1977 a$

Sejarah Nasional Indonesia, Jilid I, Jakarta: Balai Pustaka.

$1977 b$

Wales, H.G. Quaritch, 1953

Sistim-sistim Penguburan Pada Akhir Masa Perundagian Di Bali,(Desertasi), Jakarta.

The Mountain of God A Study in Early Religion and Kingship, Bernard Quaritch Ltd. 